\title{
Konstruksi dan Kontestasi Kuasa Perempuan pada Naskah Drama Les Bonnes Karya Jean Genet
}

\author{
The Power Construction of Women Contestation in "Les Bonnes" by Jean Genet
}

\author{
Ida Bagus Gede Aric Surya Lesmana ${ }^{1}$, Wening Udasmoro ${ }^{2, *}$, \\ dan Arifah Arum Candra Hayuningsih ${ }^{3}$ \\ ${ }^{1,2,3}$ Fakultas Ilmu Budaya, Universitas Gadjah Mada \\ ${ }^{1}$ Email: bagus.gede.a@mail.ugm.ac.id \\ 2,*Correspondence email: udasmoro@ugm.ac.id \\ ${ }^{3}$ Email: arum.candra@ugm.ac.id
}

Received: 19 September 2020 Revised: 20 Januari 2021 Accepted: 21 Januari 2021

\begin{abstract}
This research aims to portray the social categories such as social class and gender that construct the oppression experienced by women in the drama script Les Bonnes written by Jean Genet. This contestation appears as a result of an interaction between three main characters in the drama: Claire and Solange, as maids and Madame as their employer. Madame is a rich woman who treats them badly because of their social background as poor women. As a result of her treatment, Claire and Solange aim to kill their employer as the way out to be free from Madame's oppression. They create an assassination simulation to obtain their objective. To analyze this problem, this research uses the concept of habitus, capital, and arena from the theory of cultural production of Pierre Bourdieu. The method used in this article is a textual analysis method. The material objects are the drama script, Les Bonnes. The corpus data is taken from the words, sentences, and paragraphs containing the expression correlated with the contestations of power. The data is then analyzed using the lenses from the concept of habitus and cultural arena by Pierre Bourdieu. The finding shows that the habitus forms a constant and repetitive interaction among the subjects. It is influenced by the subjects' position based on the social capital they possess. The position is characterized by two classes: the dominant and the worker that contribute to the form of contestations in Les Bonnes.
\end{abstract}

Keywords: habitus, capital, gender, social class, contestation

Abstrak: Tujuan penelitian ini adalah untuk memperlihatkan kategori-kategori kelas sosial dan gender yang membentuk opresi yang dialami para tokoh perempuan dalam naskah drama Les Bonnes karya Jean Genet. Kontestasi ini muncul dalam interaksi antara tokoh Claire dan Solange sebagai pelayan dengan Madame sebagai majikan. Madame adalah seorang perempuan kaya yang memperlakukan mereka dengan sangat buruk. Kedua asisten rumah tangga ini berniat untuk membunuh majikan mereka sebagai jalan keluar agar terbebas dari belenggu kekuasaan Madame. Cara yang mereka lakukan adalah dengan memainkan sebuah drama pelayanmajikan sebagai simulasi pembunuhan. Penelitian ini menggunakan perspektif Pierre Bourdieu untuk menguraikan habitus, modal dan arena. Naskah ini diteliti dengan menggunakan metode analisis isi dengan objek material berupa naskah drama Les Bonnes. Korpus data yang digunakan adalah kata, kalimat, paragraf terkait dengan kontestasi kekuasaan. Data tersebut kemudian dianalisis menggunakan teori habitus dan arena kultural Pierre Bourdieu. Temuan penelitian ini adalah bahwa habitus yang ditemukan merupakan bentuk dari sosialisasi antar tokoh melalui interaksi yang repetisi dan dipengaruhi oleh posisi yang ditempati yang tergantung dari kepemilikan modal sosial. Selanjutnya, pemosisian tokoh dalam naskah drama ini dilihat sebagai pembagian kelas sosial yang diklasifikasikan menjadi dua yaitu kelas dominan dan kelas pekerja (terdominasi). Pada pembahasan terakhir, dari uraian melalui perspektif Bourdieu ditemukan bentuk-bentuk kontestasi dan perlawanan dalam naskah drama Les Bonnes.

Kata kunci: habitus, modal, gender, kelas sosial, kontestasi

To cite this article:

Lesmana, I., Udasmoro, W., \& Hayuningsih, A. (2021). Konstruksi dan Kontestasi Kuasa Perempuan pada Naskah Drama Les Bonnes Karya Jean Genet. Diglosia: Jurnal Kajian Bahasa, Sastra, dan Pengajarannya, 4(1), 6578. https://doi.org/10.30872/diglosia.v4i1.124 


\section{A. PENDAHULUAN}

Perempuan selalu diposisikan sebagai mahkluk kedua setelah laki-laki (Beauvoir, 1949). Hal ini berdampak pada pemosisian perempuan di dalam tubuh masyarakat yang mengakibatkan adanya ketimpangan relasi kekuasaan antara lakilaki dan perempuan. Ketimpangan relasi ini mengakibatkan perempuan selalu mendapatkan opresi dalam segala bentuk seperti pembatasan-pembatasan haknya sebagai manusia.

Ketertindasan yang dialami oleh kaum perempuan dianggap sebagai dampak dari mengakarnya sistem patriarki di tubuh masyarakat. Sistem patriarki ini dilihat sebagai bentuk pengagungan kaum laki-laki. Feminisme sosialis setuju dengan feminisme Marxis bahwa kapitalisme adalah sumber opresi terhadap perempuan, dan dengan radikal feminis bahwa patriarki adalah sumber dari segala opresi terhadap perempuan (Tong, 2006). Sistem patriariki dianggap melahirkan sifat superioritas pada kaum laki-laki dengan segala haknya yang tidak terbatas. Dominasi-dominasi yang dilakukan oleh kaum laki-laki terjadi di berbagai ruang, baik di ranah publik maupun ranah privat (Bourdieu, 2010). Ketika kaum laki-laki menjadi sosok yang superioritas, maka harus ada yang berada di posisi yang lemah atau inferior.

Maka posisi sebagai yang inferior disandangkan kepada kaum perempuan dengan segala batasan-batasan yang diperlakukan. Batasan-batasan ini lah yang membuat perbedaan hak dan kewajiban di antara laki-laki dan perempuan, yang membuat adanya pembeda antara kaum laki-laki dan kaum perempuan. Ketidakpuasan akan hal ini dimulai dari munculnya gerakan feminis gelombang pertama pada abad ke-19 di Eropa.

Pada gelombang pertama, gerakan feminis memperjuangkan kaum perempuan untuk memiliki hak muncul di ruang-ruang publik seperti pendidikan, akses ke lapangan pekerjaan serta mendapatkan kesempatan dalam pemilihan umum. Setelah itu, muncul gerakan feminisme gelobang kedua yang memperjuangkan hak-hak perempuan pada wilayah-wilayah publik yang lebih luas seperti yang diperjuangkan gerakan kaum feminis liberar National Organization for Women (NOW) di Amerika Serikat. NOW memperjuangkan peningkatan status perempuan dengan menerapkan tekanan legal, sosial dan lain-lain terhadap berbagai lembaga (Tong, 2006). Gelombang pertama dan kedua memiliki kesamaan kerangka perjuangan yaitu membahas persoalan tentang relasi laki-laki dan perempuan. Namun hal ini mendapatkan kritik karena gerakan dianggap hanya mewakili kepentingan orang kulit puhit kelas atas. Kritik ini muncul menanggapi pandangan-pandangan yang dibawa berdasarkan asumsi bahwa secara universal perempuan memiliki nasib yang simetris di mana pun ia berada. Pemahaman ini disebut sebagai abstract universalism (Udasmoro, 2015, hal. 3).

Menanggapi hal itu, feminisme gelombang ketiga menitikberatkan persoalan pada keberadaan perempuan yang berbeda antara yang satu dengan yang lain yang tidak dapat disamakan substansi persoalannya. Persoalan gender difference ini dikemukakan oleh Chandra Mohanty (1984) dalam Under Western Eyes: Feminist Scholarship and Colonial Discourse yang melihat bahwa tidak adanya persamaan persoalan di antara perempuan. Untuk melihat perbedaan ini, dibutuhkan interseksi antara gender dan aspek-aspek lainnya seperti kelas sosial sebagai upaya melihat adanya ketimpangan di antara masing-masing individu yang terlibat. 
Fokus penelitian ini untuk melihat bagaimana konstruksi kelas sosial di dalam tubuh perempuan sehingga mampu melakukan kontestasi dengan lawannya, bahkan sesama perempuan. Menurut Bourdieu, seseorang membutuhkan modal dan habitus yang mendukungnya untuk dapat berkontestasi di dalam sebuah arena (Bourdieu, 2016). Habitus merupakan struktur subjektif yang terbentuk dari pengalaman individu dengan individu lainnya di dalam struktur objektif sebuah ruang sosial. Melalui Perspektif Sosiologi Pierre Bourdieu, ruang sosial yang ditempatinya ini selanjutnya disebut dengan arena. Maka, habitus mengacu pada sekumpulan disposisi yang tercipta dan terformulasi melalui kombinasi struktur objektif dan sejarah personal (Bourdieu, 2004). Bourdieu percaya bahwa disposisi-disposisi ini merupakan sumber praksis seorang individu di masa yang akan datang. Habitus juga disebut sebagai ketidaksadaran kultural yang dipengaruhi oleh sejarah seorang individu sehingga secara tidak sadar dianggap alamiah karena habitus didapat dari hasil pembelajaran (Subiyantoro, Marsono, \& Udasmoro, 2017).

Proses internalisasi pada diri agen membutuhkan waktu yang cukup lama dan bertahannya pun cukup lama (durable) juga, namun bukan berarti hasil dari internalisasi-yang selanjutnya disebut habitus-ini bersifat permanen, sifat ini disebut dengan istilah hysteresis de l'habitus. Habitus yang menubuh di diri agen dalam waktu yang lama membuatnya tidak lagi menanyakan bagaimana pemahamannya tentang dunia-dalam hal ini dikerucutkan sebagai ruang sosial. Sikap ini selanjutnya disebut dengan doxa. Modal tersebut tidak hanya berupa modal ekonomi yang berpusat terhadap kepemilikan harta dan alat-alat produksi ekonomi (Jenkins, 2004). Namun modal oleh Bourdieu dikembangkan menjadi modal sosial, modal kultural dan modal simbolik.

Modal ekonomi dilihat dari kepemilikan berbagai bentuk seperti uang, perhiasan, emas barang mewah serta bentuk-bentuk lainnya yang bersifat nyata dan dapat dipegang. Modal Sosial diukur dari jaringan relasi dan orang-orang yang dikenalinya. Modal simbolik merupakan modal yang membutuhkan pengakuan khusus dari masyarakat seperti gelar kebangsawanan dan lain sebagainya. Modal kultural bisa juga disebut modal budaya yang diperoleh dari hasil pembentukan dan internalisasinya sejak kecil dalam lingkungan keluarga atau lingkungan komunitas. Modal-modal ini yang nantinya akan menentukan seseorang akan berada di posisi mendominasi atau terdominasi.

Dalam karya Jean Genet (1976) ini, terdapat fenomena serupa yang membahas hal serupa di dalam karyanya dengan judul Les Bonnes. Les Bonnes menceritakan tentang dua saudari, Claire dan Solange, yang menjadi seorang pelayan yang sedang melakukan perlawanan terhadap bentuk kekerasan dan perbudakan yang dilakukan oleh majikannya yang dalam naskah ini disebutkan dengan nama Madame. Perlawanan yang mereka lakukan pertama-tama dengan membentuk drama pelayanmajikan yang dimainkan oleh mereka sendiri. Walaupun demikian, drama yang diciptakan oleh dua saudari tersebut merupakan rencana pembunuhan yang akan dilakukannya ketika mereka merasa mampu dan memiliki waktu yang tepat. Uniknya, semua tokoh dalam karya Jean Genet ini merupakan perempuan dan peristiwa kontestasi terjadi di sesama kelompok perempuan. Kendati demikian, kontestasi yang terjadi di antara tokoh perempuan disinyalir sebagai adanya ketimpangan perbedaan kepemilikan modal yang dipertarungkan di dalam arena yang mereka tempati yaitu strukur pelayan-majikan di dalam rumah Madame. 
Pada akhirnya, rencana yang telah disusun Claire dan Solange tidak mencapai titik kesuksesannya karena terhambat kepemilikan modal dan habtius yang membuat mereka tidak bisa mengingkari dirinya sebagai pelayan. Di akhir penceritaan, kekecewaan Solange dan Claire berujung pada jalan lain yang dipilihnya. Solange yang saat itu berperan sebagai pelayan menyuguhkan teh beracun kepada Claire yang memerankan sosok Madame. Setelah menenggak teh beracun, Claire mati dan Solange merasa bahwa ia telah berhasil membunuh Madame, walaupun pada kenyataanya yang mati adalah saudarinya sendiri.

Beberapa penelitian yang menjadi acuan tulisan ini antara lain analisis mengenai habitus dan kekuasaan dalam drama "La Tragédie de Phèdre" karya Racine (Udasmoro, 2012b), analisis novel Prancis di masa Perang Dunia Kedua yang yang memperlihatkan bahwa bahasa membentuk dan dibentuk oleh kelas sosial (Udasmoro \& Shahab, 2013), dan paradigma teori arena poduksi kultural karya sastra dengan mengacu pada pemikiran Pierre Bordieu (Karnanta, 2013). Selain itu, tulisan ini juga mengacu pada Dan Kumala (2007) mengenai kontestasi kekuasaan yang berkaitan dengan perubahan habitus dalam drama Oleanna karya David Mamet. Terakhir, naskah drama ini juga banyak menarik para peneliti sastra, misalnya Cox (2014) yang membahasa tentang representasi Barat dan misogini dan Aristanty (2014). Tulisan ini mencoba menelisik hubungan modal kultural yang dimiliki oleh karakter-karakter pada Naskah Les Bonnes yang belum disentuh oleh para peneliti sastra yang lain. Artikel lain terkait dengan Les Bonnes juga ditulis oleh Cynthia Running-Johnson (1990) dalam tulisannya yang mencoba melihat karya Jean Genet ini dengan perspektif Luce Irigaray dan Hélène Cixous yang lebih melihat persoalan perempuan dengan perspektif postfeminisme. Tulisan lain juga ditulis oleh Trias Desy Aristanty (2014) yang melihat Les Bonnes ini dengan perspektif exsitensialisme dengan meletakkannya sebagai sebuah absurditas. Penelitian ini lebih melihat bahwa modal kultural sangat menarik untuk dikaji di dalam sastra karena setiap karakter dalam naskah drama Les Bonnes memiliki latar belakang sosial, gender dan pendidikan yang berbeda, sehingga mengakibatkan terjadinya kontestasi antara si pelayan dan si majikan yang ada pada narasi drama.

\section{B. METODE}

Metode adalah cara yang digunakan peneliti secara bertahap untuk melakukan penelitian (Udasmoro, 2012a, hal. 35). Metode yang digunakan dalam penelitian ini adalah metode analisis tekstual. Metode ini digunakan untuk mempelajari faktorfaktor dominasi majikan dan pelayan serta hubungannya yang terdapat di dalam dialog antar tokoh. Objek material yang digunakan adalah naskah drama Les Bonnes karya Jean Genet. Sedangkan objek formal dari penelitian ini adalah konsep-konsep habitus dan kontestasi modal kultural yang direpresentasikan oleh tokoh-tokoh di dalam naskah drama Les Bonnes.

Teknik pengumpulan data menggunakan teknik baca dan teknik catat. dengan menuliskan kata dan kalimat dalam bentuk dialog yang berhubungan dengan konsep habitus, doxa, dan modalitas serta menginterpretasikan data tersebut untuk melihat arena dan bentuk kontestasi yang ada melalui teori habitus Pierre Bourdieu (Bourdieu, 2016; Karnanta, 2013). Penelitian ini akan terfokus pada narasi-narasi di dalam objek material yang berhubungan dengan persoalan kontestasi perempuan. 


\section{PEMBAHASAN}

Oleh Marx, posisi sosial hanya didefinisikan dengan mengacu pada satu posisi dalam hubungan-hubungan produksi ekonomi dan mengabaikan hubunganhubungan produksi budaya. Demikian juga semua pertentangan yang menstruktur bidang sosial tidak dapat direduksi ke oposisi antara pemilik dan bukan pemilik sarana produksi ekonomi; maka teori itu hanya diorganisir dalam dua blok (Haryatmoko, 2016, hal. 35). Namun, pemisahan antara pemilik dan bukan pemilik sarana produksi ekonomi tidaklah cukup untuk menjelaskan siapa yang mendominasi dan siapa yang didominasi di dalam sebuah struktur sosial. Melihat fenomena ini, Bourdieu menaruh perhatian lebih kepada bidang-bidang lainnya selain bidang ekonomi dan menawarkan konsep habitus dan doxa serta arena untuk menggambarkan kelompok yang mendominasi dan kelompok yang terdominasi.

\section{Habitus dan Doxa sebagai Pembeda antara Pelayan dan Majikan}

Habitus yang tumbuh di diri seorang agen merupakan hasil dari internalisasi struktur sosial. Dalam praktiknya, sturuktur sosial yang ada merupakan struktur yang diciptakan oleh pemilik kuasa atau dalam hal ini disebut sebagai yang mendominasi. Untuk melihat kelompok yang mendominasi dan terdominasi antara Solange dan Claire sebagai pelayan dengan Madame sebagai majikan dapat dilihat dari habitus yang dimiliki masing-masing tokoh. Pertama-tama, hal yang bisa dilhat yaitu habitus patuh para pelayan yang tampak pada dialog berikut:

\section{Madame :... Le récepteur... Qui a encore déroché le récepteur et pouquoi? On a téléphoné? \\ Claire : C'est moi. C'est quand Monsieur....}

(Genet, 1976, hal. 80-81)

Terjemahan:

Madame :... Gagang telepon.... Siapa yang membiarkan gagang telepon tergeletak begitu saja? Apakah tadi ada panggilan masuk?

Claire : Itu saya. Itu Monsieur yang menelpon....

Di situasi yang terdesak dan panik. Claire dan Solange tidak bisa mengingkari dirinya sebagai pelayan dengan berbohong di hadapan Madame sebagai majikannya, meskipun pada kenyataanya mereka memiliki kesempatan untuk berbohong dan menutupi identitas si penelpon. Keputusan Claire untuk menjawab jujur pertanyaan Madame tidak terlepas dari habitus yang sudah menubuh di dirinya. Sehingga apa yang dilakukannya sudah merupakan bagian dari tindakan alam bawah sadarnya sebagaimana doxa bekerja pada agen yang terdominasi.

Bahkan, permainan drama yang biasa dan sering kali Claire dan Solange mainkan tidak banyak mempengaruhi bagaimana habitus yang sudah mengakar di dalam dirinya sebagai pelayan. Terlebih lagi melihat bahwa drama tersebut adalah rencana yang telah mereka susun untuk Madame. Dengan adanya fenomena seperti ini, maka hysteresis de l'habitus sebagai sifat habitus yang tahan lama namun tidak permanen mampu dipertanggung jawabkan. 
Ada pula habitus patuh yang tampak pada dialog berikut.

Solange $\quad$....j'ai descendu l'escalier le plus lentement possible, j'ai passé par les rues les moins fréequentées, $j^{\prime} y$ trouvais des nuées de taxis. Je ne pouvais plus les éviter. Je crois que j'en ai arrêté un sans m'en rendre compte.

(Genet, 1976, hal. 92)

Terjemahan:

Solange : ... aku menuruni tangga selambat mungkin, aku melewati jalanan yang jarang orang-orang lewati, dan disana aku menemukan sebuah taksi. Aku tidak bisa menghindarinya lagi. Tanpa aku sadari, aku memberhentikan salah satunya.

Karena habitus patuh yang sudah menubuh di dirinya, secara tak sadar ia melakukan apa pun yang diperintahkan. Padahal dengan ia tidak memberhentikan salah satu taksi yang ditemui, ia bisa mengulur waktu lebih lama lagi hingga Claire memiliki cukup waktu untuk melancarkan aksinya membunuh Madame. Solange sudah berada di tahap di mana ia tidak mempertanyakan apa yang diperintahkannya lagi. Fenomena ini bisa dilihat sebagai gambaran bagaimana cara kerja doxa pada diri seorang agen. Lebih jelas lagi tampak ketika Solange mengakui hal tersebut di dalam kalimat "Tanpa aku sadari, aku memberhentikan salah satunya...."

Tindakan-tindakan yang menggambarkan habitus Claire dan Solange sebagai pelayan tidak terlepas juga dari habitus Madame sebagai majikan yang menjadi sebab terinternalisasinya habitus-habitus. Dapat dikatakan juga bahwa tindakan-tindakan Madame merupakan cara bagaimana yang mendominasi melakukan pemertahanan posisi terhadap tindakan yang dilakukan oleh yang terdominasi. Berikut habitus arogansi yang dimunculkan Madame sebagai upaya menunjukkan pembeda dan pemertahanan posisinya sebagai majikan.

Madame : Je ne suis pas lasse. Cessez de me traiter comme un impotente. A paritr d'ajourd'hui, je ne suis plus la maîtresse qui vous permettait de conseiller et d'entretenir sa paresse. Ce n'est pas moi qu'il faut plaindre. Vos gémissements me seraient insupportables. Elle m'étouffe. Votre gentillesse qui depuis des années n'a jamais vraiment pu devenir affectueuse. Et ces fleurs qui sont là pour feter juste le contraire d'une noce! Il vous manquait de fair du feur pour me chauffer! Est-ce qu'il y a du feu dans sa cellule?

(Genet, 1976, hal. 71)

Terjemahan:

Madame : Aku tidak lelah. Berhenti memperlakukanku seperti orang yang tak berdaya. Mulai hari ini, aku bukan lagi majikanmu yang memberikanmu ijin untuk menganjurkanku saran apa pun itu dan memintaku untuk bermalas-malasan. Bukan aku yang seharusnya dikeluhkan. Aku sudah tak tahan dengan eranganmu. Kebaikan yang kamu lakukan mengangguku. Memenuhiku. Membuatku tersedak. Kebaikanmu yang selama bertahun-tahun tidak pernah benar-benar sebuah kasih sayang yang tulus. Dan bunga-bunga disana, itu hanya untuk mengejekku bukan? 
Dalam dialog tersebut, Madame berusaha lebih untuk menunjukkan bahwa ia merupakan seorang majikan yang memiliki kuasa atas diperbolehkannya Claire dan Solange untuk berbicara. Dengan cara tersebut, Madame berusaha tetap mempertahankan dominasinya terhadap Claire dan Solange serta mengukuhkan dirinya kembali di hadapan Claire dan Solange sebagai majikan. Pada adegan tersebut, dominasi dalam hal ini bukanlah dominasi yang dilakukan melalui kekerasan, namun melalui kekerasa simbolis sehingga Claire dan Solange memiliki doxa sebagai pelayan - kelas yang berbeda dari majikannya. Madame melakukannya sebagai pemahaman bahwa ia harus memposisikan dirinya sebagai majikan — dalam konsep Bourdieu sebagai kelas dominan.

Bourdieu (2004) menyatakan bahwa strategi agen-agen dan lembaga-lembaga yang terlibat di dalam pergulatan, yaitu pengambilan posisi-posisi, bergantung pada posisi yang mereka tempati di dalam struktur arena. Melalui mediasi disposisidisposisi yang membentuk habitus mereka, taraf di mana hal ini sudah menjadi kepentingan mereka untuk memelihara atau mentransformasi sturktur distribusi ini, dan karenanya mempertahankan atau menumbangakn aturan-aturan permainan yang ada.

Tindakan Madame untuk membentuk pembeda pun dilakukan secara berulangulang dan hal ini bisa mempertanggung jawabkan konsep "structure structurante" dan "structure structurée" di mana sikap yang diambil oleh Madame merupakan hasil dari strukturisasi struktur. Pada dialog berikut, Madame berusaha mempertahankan posisinya dan lebih menjelaskan lagi bahwa para pelayan dan majikan tidak berada pada kelas yang sama.

Madame : ... J'aurai de nouvelles et de plus belles toillettes. Et vous m'aiderez en portant mes vieilles robes. En vous les donnat, j'attireai peut-être la clémence sur Monsieur. On ne sait jamais.

(Genet, 1976, hal. 76)

Terjemahan:

Madame : ... Aku akan memiliki pakaian paling baru dan paling indah. Dan kamu akan membantuku membawa gaun-gaun lamaku. Dengan memberikannya kepadamu, mungkin aku akan mendapatkan permintaan grasi untuk Monsieur. Kita tidak pernah tahu.

Secara padanan kata, terdapat keterhubungan makna yang kontradiktif antara "pakaian paling baru dan paling indah" dengan "gaun-gaun lamaku". Kata "baru" diperuntukkuan bagi diri Madame sebagai seorang majikan dan kata "lama" diperuntukkan bagi Claire dan Solange sebagai para pelayan. Terlebih lagi, itikadnya untuk memberikan gaun-gaun kepada Claire dan Solange adalah sebuah bentuk pengharapan adanya balasan dari pengadilan dengan memberikan grasi untuk Monsieur. Dalam artian bahwa para majikan akan terlihat sebagai mereka yang baik ketika memberikan sesuatu yang para pelayannya tidak miliki. Secara tidak langsung, hal tersebut tampak sebagai bentuk penghinaan kepada Claire dan Solange sebagai seorang pelayan yang selalu dipandang rendah oleh Madame.

Dalam kondisi vis-a-vis, mereka yang beroposisi akan selalu membuat perbedaan atau menjadi sesuatu yang berbeda dari lawannya. Jenkins (2004) dalam bukunya 
Membaca Pikiran Pierre Bourdieu tentang Consendence Strategy yang oleh Pierre Bourdieu djelaskan sebagai tindakan merendahkan diri sebagai usaha untuk melejitkan dirinya sendiri sehingga dapat memenangkan kontestasi.

\section{Komposisi Modalitas sebagai Alat Kontestasi}

Modal tertentu akan sangat berpengaruh jika seorang agen dengan habitus yang dimiliki mampu memanfaatkan modal yang dimiliki-tergantung dari arena yang ditempatinya. Dua aspek ini yang nantinya akan menentukan bagaimana seorang individu mampu menempati posisi tertentu di sebuah arena. Dalam hubungan antara pelayan dan majikan, mereka memiliki perbedaan kepemilikan modal sehingga nantinya dapat diklasifikasikan ke dalam kelas tertentu antara yang terdominasi dan yang mendominasi.

Dalam naskah drama Les Bonnes, ketidakberdayaan Claire dan Solange serta kekuasaan Madame dapat dijelaskan dengan modal-modal yang dimilikinya. Karena modal-modal yang dimiliki mempengaruhi bagaimana seorang agen melakukan perlawanan.

Menggunakan konsep modal dari Pierre Bourdieu, Claire dan Solange tampak memiliki modal yang tidak dimiliki Madame yaitu modal sosial. Pertama, hubungan saudari yang Claire dan Solange miliki adalah salah satu bentuk modal sosial. Selain itu, terdapat modal sosial lainnya yang tampak pada dialog berikut:

\section{Solange $\quad$.... Le bourreau m'accompagne, Claire! Le bourreau m'accompagne! (Elle rit.) Elle sera conduit en cortège par toutes les bonnes du quartier, par tous les domestiques qui ont accompagné Claire à sa dernière demeure.}

(Genet, 1976, hal. 108)

Terjemahan:

Solange :... Algojo menemaniku! (Ia tertawa). Aku akan diiringi dalam prosesi itu oleh seluruh pelayan yang ada di wilayah ini, oleh semua para pekerja domestik yang menemani Claire ke peristirahatan terakhirnya.

Modal sosial pada dialog ini muncul dalam bentuk solidaritas. Solange merasa bahwa para pekerja domestik yang ada di wilayahnya merasa senasib sepenanggungan ketika mengetahui bahwa Claire dan Solange akan dihukum mati. Terlebih lagi, hukuman yang ia dapat dikarenakan keberaniannya menjebloskan Monsieur ke dalam penjara dengan sebuah surat tuduhan pencurian. Solidaritas ini muncul sebagai gambaran adanya persatuan diantara para pekerja yang merasa terdominasi oleh struktur yang ada di dalam hubungannya antara pelayan dan majikan, bawahan dan atasan, buruh dan tuan. Namun modal ini menjadi sesuatu yang tak berarti ketika orang-orang yang tergabung di dalamnya juga mengalami ketidakberdayaan akibat struktur hubungan pelayan-majikan. Ketidakberdayaan ini juga menjadi lebih buruk ketika Claire dan Solange tidak memiliki modal ekonomi. Hal ini dapat dilihat dari dialog berikut.

Claire : Où irions-nous? Que ferions-nous pour vivre. Nous sommes pauvres!

(Genet, 1976, hal. 95) 
Terjemahan:

Claire : Kita akan pergi kemana memangnya? Apa yang akan kita lakukan untuk bertahan hidup. Kita miskin!

Ketidakpemilikan modal ekonomi pada diri Claire dan Solange membuat mereka merasa terperangkap walaupun mereka merasa memilki modal sosial dari teman-teman sejawatnya sesama pekerja. Hal ini nantinya akan menjadi faktor penting bagaimana Claire dan Solange menentukan gaya perlawanannya terhadap Madame.

Berbeda dengan Madame yang memiliki modal ekonomi, modal sosial dan modal kultrual. Kepemilikan tiga jenis modal ini menjadi faktor besar mengapa ia bisa mendominasi dan membuat yang terdominasi tidak berdaya. Modal ekonomi tidak hanya berbentuk uang, tetapi bisa juga berbentuk benda mewah atau berharga. Hal ini dapat dilihat pada petunjuk latar berikut.

La chambre de Madame. Meubles Louis XV....

(Genet, 1976, hal. 15)

Terjemahan:

Di ruangan Madame. Furnitur- furnitur Louis XV....

Selain itu, pada dialog lainnya juga menunjukkan bahwa Madame memiliki berbagai modal ekonomi dalam bentuk benda berharga. Hal ini muncul ketika Claire dan Solange memainkan drama pelayan-majikan.

Claire : Disposez mes toilettes. La robe blanche pailleteé. L'éventail, les émeraudes.

Solange : Tous les bijoux de Madame?

Claire : Sortez-les. Je veux choisir.

(Genet, 1976, hal. 17)

Terjemahan:

Claire : Rapikan alat riasku. Siapkan gaun putihku yang berkilau. Kipas sekaligus perhiasan zamrudku.

Solange : Semua perhiasan milik Madame?

Claire : Keluarkan semua.

Setelah berbagai benda berharga milik Madame yang dapat digolongkan ke dalam kategori modal ekonomi. Selanjutnya, modal sosial yang dimiliki Madame tampak pada dialog berikut:

Madame : Tu connais des choses que j'igonre. Gardes ou gendarmes, ils on emmené Monsieur. Je quitte à l'instant la femme d'un magistrat. Claire!

(Genet, 1976, hal. 67)

Terjemahan: 
Madame : Kamu tahu tentang sesuatu yang aku tak tahu. Penjaga atau polisi, mereka membawa pergi Monsieur.Sekarang, aku hanya tinggal istri seorang pejabat. Claire!

"Magistrat" pada dialog ini dapat berarti seorang hakim, seorang walikota, bahkan pada bidang politik dapat berarti menteri atau jabatan lainnya. Dapat diketahui bahwa Madame memiliki suami yang berprofesi sebagai seorang pejabat. Yang secara tidak langsung, Madame sebagai istrinya mendapat pengaruh juga oleh status yang disandang suaminya dan memiliki berbagai jaringan atas jabatan suaminya.

Solange :... Madame et Monsieur m'appelleront mademoiselle Solange Lemercier.... A la sortire du cimetière, tous les domestiques du quartier défilaient devant moi comme si j'eusse été famille. J'ai si souvent prétendu qu'elle faisait partie de la famille... Maintenant, nous sommes mademoiselle Solange Lemercier. La femme Lemercier. La Lemercier. La fameuse criminelle....

(Genet, 1976, hal. 109)

Terjemahan:

Solange :... Madame dan Monsieur akan memanggilku nona Solange Lemercier.... Beranjak dari pemakaman, semua pelayan dari tetangga lain lalu lalang melewati saya seolah-olah saya adalah anggota keluarga. Saya sering mangakui kalau diri saya memang bagian dari keluarga ini.... Sekarang, kita adalah nona Solange Lemercier. Penjahat terkenal....

Dialog ini menunjukkan bagaimana Claire dan Solange mengidam-idamkan untuk mempunyai gelar bangsawan sama seperti majikannya. Percakapan tersebut muncul ketika Solange menumpahkan semua perasaan kesalnya ketika gagal melakukan rencana pembunuhan dan merasa putus asa terhadap situasi yang mereka alami. Bahkan ia membayangkan jika berhasil membunuh dan menghadiri pemakaman majikannya, ia akan tampak seperti anggota dari keluarga Lemercier. Kata "Lemercier" dapat dilihat sebagai pengakuan khusus yang Madame dapatkan karena merupakan bagian dari keluarga bangsawan dan ini termasuk dala kategori modal kultrual yang dimiliki Madame.

\section{Arena Kontestasi dan Gaya Perlawanan}

Arena menurut Bordieu adalah suatu arena sosial yang yang di dalamnya terdapat perjuangan atau manuver terjadi untuk memperebutkan sumber atau pertaruhan yang dipertaruhkan - seperti benda kultural (gaya hidup), perumahan, kemajuan intelektual (pendidikan), pekerjaan, tanah, kekuasaan (politik), kelas sosial, prestise atau lainnya-dan mungkin berada pada tingkatan yang berbeda dengan spesifikasi dan derajat yang konkret (Jenkins, 2004, hal. 124)

Dalam naskah drama Les Bonnes, hubungan antar agen bersifat vis a vis, saling berlawanan. Claire dan Solange merupakan pelayan dan Madame adalah seorang majikan. Hubungan di antara mereka adalah hubungan antara pelayan dan majikan. Sehingga dalam interaksinya, Claire dan Solange selalu bertindak sebagai pelayan 
yang patuh dan setia di hadapan Madame, namun menjadi diri yang berbeda ketika memainkan drama pelayan-majikan yang dibuatnya. Ini disebut dengan disposisi yang diperoleh dalam posisi yang ditempati mengimplikasikan penyesuaian diri dengan posisi mereka.

Mengutip Goffman (2007) hal ini disebut dengan sense of one's place (sikap tahu diri tentang tempat masing-masing). Terlihat perbedaan interaksi Claire dan Solange ketika memainkan drama pelayan-majikan dengan interaksinya langsung saat berhadapan dengan Madame. Perbedaan ini dapat dilihat sebagai ketidakberdayaan Claire dan Solange ketika berhadapan langsung dengan Madame. Namun mereka bisa melakukan tindakan-tindakan yang dilihat sebagai bentuk perlawanan ketika memainkan drama pelayan-majikan.

Ketidakberdayaan yang dialami mereka karena ketidakpemilikan modal yang kuat serta habitus dan doxa lantas membuat mereka menjadi pihak yang terdominasi oleh Madame. Hal ini tidak lantas mereka biarkan begitu saja. Mereka membuat alternatif cara untuk melakukan perlawanannya dengan membuat drama pelayanmajikan. Jalan keluar ini membuat mereka mampu melakukan tindakan-tindakan perlawanan karena berada di luar kekuasaan Madame.

Di dalam drama pelayan-majikan, mereka membentuk gambaran Madame. Namun gambaran yang dibentuk tidak menghadirkan rasa yang sama seperti berhadapan dengan Madame secara langsung. Maka dari itu, walaupun Claire berperan sebagai Madame, mereka merasa sedang di luar kekuasaan Madame atas ketidakhadiran Madame yang nyata di arena yang mereka buat. Cara-cara seperti ini adalah manuver-manuver perlawanan untuk merebut kekuasaan di dalam sebuah arena.

Karena yang diperebutkan adalah kuasa-kuasa yang ada di dalam dominasi Madame, maka Claire, Solange dan Madame terjebak pada sebuah struktur arena kekuasaan. Kekuasaan itu terdiri atas Claire dan Solange yang berusaha mentransformasi struktur (opresi dan diskriminasi yang mereka alami) dan Madame yang berusaha mempertahankan posisinya. Pada akhirnya, terjadilah kontestasikontestasi yang berasal dari pemosisian pelayan-majikan oleh Claire dan Solange atas diskriminasi yang mereka peroleh.

\section{PENUTUP}

Berlatar belakang hubungan majikan-pelayan, dalam naskah drama Les Bonnes tampak bagaimana lahirnya dominasi dan yang terdominasi dilihat melalui teori habitus, modal dan arena milik Pierre Bourdieu. Selain itu, teori interseksi antara gender dan kelas sosial juga digunakan untuk melihat adanya bentuk opresi yang dilakukan antara sesama perempuan.

Claire dan Solange yang merupakan seorang pelayan terperangkap dalam belenggu kuasa Madame sebagai majikannya. Upaya-upaya yang mereka lakukan baik secara langsung dan tidak langsung tidak dari belenggu Madame kecuali kematian. Perlawanan yang mereka lakukan dituangkan dalam bentuk drama pelayan-majikan buatannya. Hal ini dilakukan berulang-ulang sekaligus menjadi sebuah persiapan untuk melakukan perlawanannya secara langsung ketika berhadapan dengan Madame. Kendati demikian, persiapan dan perlawanan yang dilakukan oleh Claire dan Solange selalu tidak berhasil. Kehadiran Madame yang 
dianggap sebagai pemegang otoritas membuat Claire dan Solange kembali menjadi pelayan yang patuh ketika berhadapan langsung dengan Madame yang nyata.

Adanya ketidakberdayaan ini dilihat dari kesenjangan kepemilikan modal antara Claire dan Solange sebagai pelayan dan Madame sebagai majikan. Kesenjangan ini dilhat dari kepemilikan modal yang lemah dari Claire dan Solange serta kepemilikan modal Madame yang menguasai segala lini yaitu modal ekonomi, modal sosial, modal kultural dan modal simbolik. Perbedaan kekuatan yang dipengaruhi kepemilikan modal menentukan siapa yang mendominasi dan siapa yang terdominasi di dalam struktur arena di mana mereka tinggal. Efek dari dominasi ini melahirkan habitus akibat internalisasi struktur yang ada dan berlangsung dalam waktu yang lama. Habitus-habitus ini yang akhirnya melanggengkan dominasi yang nantinya akan menimbulkan kontestasi dan perlawanan dari masing-masing pihak. Seperti habitus patuh yang tidak bisa dilanggar Claire dan Solange termasuk dalam kategori sebuah bentuk doxa. Kepatuhan tersebut tidak bisa dilanggar karena Claire dan Solange sudah menganggap hal itu sebagai sesuatu yang wajar yang dilakukan sebagai pelayan terehadap majikannya. Padahal, kewajaran yang ada di struktur pemikirannya tersebut berasal dari hasil dominasi Madame sebagai majikannya. Sehingga, dengan sebuah kesadaran bahwa mereka berada dibawah belenggu kuasa Madame, perlawanan yang dibentuk oleh Claire dan Solange dengan cara membentuk arena kekuasaan alternatif dengan memainkan drama majikan-pelayan untuk meniadakan kehadiran Madame yang nyata. Begitu pula dengan Madame yang berusaha untuk mengkonservasi struktur sebagai kelas dominan melahirkan habitus arogan dan pesimis dalam bentuk rendah hati (Consendence Strategy) untuk mengangkat dirinya di hadapan Claire dan Solange agar tidak bisa melakukan perlawanan.

Melihat dari semua tokoh yang ada di dalam naskah drama Les Bonnes, dapat dilihat adanya opresi yang dilakukan sesama perempuan. Maka dari itu, akhir dari penelitian ini dapat mengungkapkan bahwa kaum perempuan tidak selalu menjadi kaum yang subordinat, tetapi bisa juga menjadi kaum yang superior karena dipengaruhi aspek-aspek lainnya seperti kelas sosial. Sehingga muncul perlawanan dan kontestasi yang terjadi antara sesama perempuan, yaitu perempuan kelas dominan yang ada di diri tokoh Madame dan perempuan kelas pekerja yang ada di diri tokoh Claire dan Solange.

\section{DAFTAR PUSTAKA}

Aristanty, T. D. (2014). Absurditas dalam Dialog Antartokoh Naskah Drama Les Bonnes Karya Jean Genet melalui Pelanggaran Maksim Kuantitas dan Relevansi (Skripsi, Universitas Brawijaya). Universitas Brawijaya, Malang. Diambil dari https://www.neliti.com/id/publications/203154/

Beauvoir, S. de. (1949). Le deuxieme sexe (Collection Soleil, Vol. 2). Paris: Gallimard. Bourdieu, P. (2004). In other words: Essays towards a reflexive sociology (M. Adamson, Penerj.). Cambridge: Polity Press. 
Bourdieu, P. (2010). Dominasi Maskulin (S. A. Herwinarko, Penerj.). Yogyakarta: Jala Sutra.

Bourdieu, P. (2016). Arena Produksi Kultural. Yogyakarta: Kreasi Wacana.

Cox, L. (2014). Misogyny, Maids, and Murderesses: Toward a Feminist Reappraisal of Jean Genet's Les Bonnes. Theatre Journal, 66, 227-240. https://doi.org/10.1353/tj.2014.0058

Genet, J. (1976). Les Bonnes: Comment jouer les Bonnes. Paris: Arbalète de Barbezat.

Goffman, E. (2007). The presentation of self in everyday life. London: Penguin Books.

Haryatmoko. (2016). Membongkar rezim kepastian pemikiran kritis post-strukturalis. Yogyakarta: Kanisius. (Yogyakarta).

Jenkins, R. (2004). Membaca Pikiran Pierre Bourdieu (Nurhadi, Penerj.). Bantul: Kreasi Wacana. (Yogyakarta).

Karnanta, K. Y. (2013). Paradigma Teori Arena Produksi Kultural Sastra: Kajian Terhadap Pemikiran Pierre Bourdieu. Poetika: Jurnal Ilmu Sastra, 1(1). https://doi.org/10.22146/poetika.v1i1.10420

Kulmala, D. (2007). "Let's take the mysticism out of it, shall we?": Habitus as Conflict in Mamet's Oleanna. Journal of Dramatic Theory and Criticism, 101-124. Diambil dari https://journals.ku.edu/jdtc/article/view/3572

Mohanty, C. T. (1984). Under Western Eyes: Feminist Scholarship and Colonial Discourses. boundary 2, 12/13(1), 333-358. https://doi.org/10.2307/302821

Running-Johnson, C. (1990). Genet's "Excessive” Double: Reading Les Bonnes through Irigaray and Cixous. The French Review, 63(6), 959-966. Diambil dari https://www.jstor.org/stable/395942

Subiyantoro, S., Marsono, M., \& Udasmoro, W. (2017). Integration of French Lexicons in New Caledonian Javanese. Humaniora, 29(1), 85-93. https://doi.org/10.22146/jh.22568

Tong, R. P. (2006). Feminist Thought: Pengantar Paling Komprehensifkepada Arus Utama Pemikiran Feminis (Kurniasih, Ed.; A. P. Prabasmoro, Penerj.). Yogyakarta: Jalasutra.

Udasmoro, W. (2012a). Bagaimana Menganalisis Sastra. Yogyakarta: Program Studi Sastra Prancis Universitas Gadjah Mada.

Udasmoro, W. (2012b). Kekuasaan di atas Pentas: La Tragedie "Phedre" dalam Perspektif Feminisme Poststrukturalis. Humaniora, 20(1), 11-17. https://doi.org/10.22146/jh.915

Udasmoro, W. (2015). Apropriasi gender dalam sastra, media dan wacana sehari-hari. Yogyakarta: Prodi Sastra Prancis, Fakultas Ilmu Budaya, Universitas Gadjah Mada.

Udasmoro, W., \& Shahab, A. (2013). Kontestasi Ideologi dalam Sastra Prancis Masa $\begin{array}{llll}\text { Perang Dunia Kedua. } & \text { LITERA, }\end{array}$ https://doi.org/10.21831/ltr.v12i02.1549 
